\title{
The COVID-19 pandemic and the challenge for innovation policy
}

\author{
ROBERT BURRELL* \\ University of Oxford and University of Melbourne \\ CATHERINe Kelly ${ }^{\dagger}$ \\ University of Bristol
}

T he scramble to develop and deliver a vaccine for COVID-19 has led to calls for the establishment of a prize fund to incentivise scientists and pharmaceutical companies to invest in the endeavour. ${ }^{1}$ The thrust of the argument will be familiar to anyone who has followed disputes over the limitations of the patent system in relation to pharmaceutical research: patents only work to create incentives if potential patent owners are able to fix prices at a level that will allow them to recoup the costs of their investment. The inability to charge such prices means that there is relatively little investment in drugs to treat conditions that blight the lives of millions in the global south or in last-line antibiotics that need to be prescribed in the smallest possible number of cases to preserve their efficacy. The market for a COVID-19 vaccine is, of course, vast and includes the world's wealthiest populations, but pharmaceutical companies know that there will be political pressure to keep prices low, with some countries already indicating that they will be willing to issue compulsory licences to force down the costs of any patented COVID-19 vaccine. $^{2}$

We have argued elsewhere that policymakers are right to be experimenting with innovation prizes as a way of incentivising research. ${ }^{3}$ Some areas of medical research would seem to be particularly well-suited to this form of policy intervention, although we need more evidence of the impact of prizes like Longitude 2014 (which seeks to incentivise the development of a point-of-care diagnostic test as a means of conserving

* Professor of Intellectual Property and Information Technology Law, University of Oxford, and Professor of Law, University of Melbourne.

$\dagger \quad$ Reader in Law, University of Bristol.

1 Daniel Hemel and Lisa Larrimore Ouellette, 'Want a corona virus vaccine, fast? Here's a solution' Time Magazine (New York, 4 March 2020) <https://time.com/5795013/coronavirus-vaccine-prize-challenge>; Chris Callaghan, 'Would a Longitude Prize speed production of a Covid-19 vaccine' Times Higher Education (28 March 2020), <www.timeshighereducation.com/blog/would-longitude-prize-speed-production-covid-19vaccine>; Alexander Tabarrok, 'Grand innovation prizes to address pandemics: a primer'

$<$ www.mercatus.org/publications/covid-19-policy-brief-series/grand-innovation-prizes-address-pandemicsprimer>; Tyler Cowan, ' $\$ 1$ million plus in emergent ventures prizes for coronavirus work'

<https://marginalrevolution.com/marginalrevolution/2020/03/1-million-plus-in-emergent-ventures-prizesfor-coronavirus-work.html>.

2 The Chilean Chamber of Deputies passed a unanimous resolution to this effect on 17 March 2020. An English translation of this resolution is available at <www.keionline.org/chilean-covid-resolution>.

3 R Burrell and C Kelly, 'Public rewards and innovation policy: lessons from the eighteenth and early nineteenth centuries’ (2014) 77 Modern Law Review 858. 
antibiotics) before we can say this with certainty. We have significant reservations, however, about whether the establishment of an innovation prize is the right policy intervention for dealing with the challenges of getting a COVID-19 vaccine into general use. It has been reported that some 35 companies and academic institutions are working on a vaccine, ${ }^{4}$ and a handful of candidates are now entering trials. There is, of course, no guarantee that any of the current efforts will bear fruit, since the development of a new vaccine is difficult and carries a high risk of failure. But it is far from clear that there are research teams currently sitting on the sidelines needing motivation to enter the fray. We need to be cautious of additional regulatory intervention in situations where the empirical evidence suggests that there are already adequate incentives to invest in a creative endeavour, a point that applies at least as strongly to the creation of prizes as it does to the extension of intellectual property rights. Scientists, engineers, research managers and funding bodies will step up when faced with a global health emergency. A handful of researchers may do so because they know that fame and quite possibly fortune will come to those who make the most noteworthy contributions to solving the current crisis. But few participants in the research push are likely to be motivated by dreams of a Nobel Prize or similar. The current crisis has revived our sense of community (panic-buying of toilet rolls notwithstanding), and people of all descriptions are bringing their expertise to bear on solving what problems they can. Engineers volunteering their time to work out how to repurpose industrial air separation units to produce medical grade oxygen or to find ways of printing plastic ventilator valves have done so without any expectation of recognition or reward. ${ }^{5}$ Rarely has the construct of bomo economicus seemed like a less safe guide for regulatory intervention.

None of this is to say that there are not likely to be significant barriers to the roll-out of a global immunisation programme. The winner of the race to produce a vaccine may well seek to patent it and, if so, there are likely to be fierce arguments over pricing. Upscaling manufacture may be difficult, particularly if manufacturers are concerned about liability for producing a vaccine that has been put through an expedited set of approvals. Distributing vaccines is likely to be a significant problem in least developed and war-torn countries, and even in some developed countries anti-vaxer sentiment may delay herd immunity. These are not trivial problems, and some will demand a regulatory response. However, once a vaccine has been developed, manufacturing will be upscaled. Governments are, by their own description, on a war footing. We are in a world where the US government has already demonstrated its willingness to use emergency powers to force a private company to manufacture ventilators. Even if this move was largely a

4 Laura Spinney, 'When will a coronavirus vaccine be ready?' The Guardian (London, 5 April 2020) <www.theguardian.com/world/2020/apr/05/when-will-a-coronavirus-vaccine-be-ready>.

5 The latter example is taken from a newspaper article on ingenuity and COVID-19: Oliver Wainwright, '10 Covid-busting designs: spraying drones, fever helmets and anti-virus snoods' The Guardian (London, 5 April 2020) <www.theguardian.com/artanddesign/2020/mar/25/10-coronavirus-covid-busting-designs>; the former is drawn from an anecdote relayed to one of the authors by someone who works in the petrochemical industry. 
matter of political theatre, ${ }^{6}$ it demonstrates that states will do what is necessary to ensure that a vaccine is produced as quickly as possible and in large quantities. ${ }^{7}$

To our minds, therefore, the current crisis does not demand an immediate innovation policy response. The challenge for innovation policy lies not in how it can get us from where we are to where we need to be. Rather, to play on an old joke, the question that needs to be asked is whether we should be starting from our current location. Hopefully, the terms of reference for public enquiries into our preparedness for the current pandemic will encompass missed research opportunities. In the meantime, it is important not to rush to judgement. Nevertheless, the early signs are that promising research opportunities were missed. In particular, scientists who had been working on a SARS vaccine have reported their frustration that funding dried up as the risks of SARS receded. If funding had been maintained and a successful SARS vaccine had been developed, we might be much closer to being able to produce a vaccine for COVID-19. ${ }^{8}$

We believe the challenge lies in moving towards a more 'proactive' innovation policy: ${ }^{9}$ one that recognises that a patent-centric and market-focused innovation model may result in underinvestment in promising treatment opportunities until a crisis is upon us, at which point - if the crisis is of a sufficient magnitude - the market may in any event be forced to give way to the command and control imperatives of the state.

Prizes could have an important role to play in building a more proactive innovation system, but issues of prize design need to be taken seriously. Innovation ecosystems are invariably complex, and this is particularly true for medical research, where there are a vast array of actors and stakeholders. History can offer insights into how a system of prizes might operate. Attention soon falls on the eighteenth-century Longitude Prize whenever innovation prizes are being discussed: recent calls for the establishment of a COVID-19 vaccination prize have all referenced this historical precursor. However, in the $\mathrm{UK}$ at least, grand innovation prizes were unusual in the eighteenth and nineteenth centuries. Much more important was the system of post hoc rewards that complemented the still-developing patent system - and ameliorated some of its failures. ${ }^{10}$ These were awarded by Parliament in response to petitions from inventors, with no ex ante guidance as to the categories of endeavour that might attract parliamentary approval. These rewards were used by the British state to endorse some of the most important discoveries of the period. Of most immediate relevance are the parliamentary payments to Edward

6 W J Hennigan, 'Inside Trump's coronavirus theatrics on war powers, ventilators and GM' Time Magazine (New York, 31 March 2020).

7 Access to specialised machinery and raw materials may well prove to be a problem, and lack of preparedness to upscale vaccine manufacture (which bodies like the World Health Organization have been warning about for years) may well produce delays and prolong the crisis. See Stanley Plotkin et al, 'The complexity and cost of vaccine manufacturing - an overview' (2017) 35(33) Vaccine 4064. The point we are making is simply that once nations like the USA are on a war footing these problems will eventually be overcome.

8 See, for example, the testimony of Professor Peter Hotez, Dean of the National School of Tropical Medicine, Baylor College of Medicine and co-Director of the Texas Children's Hospital Center for Vaccine Development, before the Congressional Committee on Science, Space and Technology, 5 March 2020: $<$ https://science.house.gov/hearings/beyond-coronaviruses-understanding-the-spread-of-infectiousdiseases-and-mobilizing-innovative-solutions $>$.

9 As to the differences between proactive and reactive innovation policies, see also 'Scientists were close to a coronavirus vaccine years ago. Then the money dried up' NBC News (5 March 2020):

<www.nbcnews.com/health/health-care/scientists-were-close-coronavirus-vaccine-years-ago-then-moneydried-n115009>, reporting the comments of Dr Jason Schwartz, Yale School of Public Health.

10 On the existence of this system of rewards running parallel to patent protection see, Burrell and Kelly (n 3). 
Jenner, developer of the smallpox vaccine, who was awarded $£, 10,000$ in 1802 and a further $f 20,000$ in 1807 . In the parliamentary debates over Jenner's petitions it was accepted by all sides that Jenner 'could expect no reward from the method of patents, which were not applicable in the present case'. ${ }^{11}$

A generalised system of rewards comes with its own limitations, not least that (like the patent system) it does not provide a proactive steer as to the types of innovation that society is seeking to incentivise. It is, in any event, more or less impossible to imagine the re-creation of a generalised reward system given modern controls on the dispersal of public funds. The future must therefore lie in prizes, but here it is important to note that the distinction between prizes and rewards is one that needs to be handled with care. The more the subject of 'a prize' is described in broad terms, and the more there is discretion to adjust the size of the prize after the nature of the invention has been revealed, the closer a prize is to a reward. If the use of prizes is to be expanded, we need to be wary of schemes that close off promising lines of enquiry by defining 'success' narrowly. It may be that by defining very specific goals, prize competitions restrict the natural creativity of scientists and discourage exploration of tangential ways of tackling the underlying problem. We also need to be sceptical of the argument that highly prescriptive victory criteria can prevent arguments over whether a prize should be awarded. The original Longitude Prize was governed by a strict set of clearly articulated criteria and yet debate over whether Harrison was treated fairly continues to this day. ${ }^{12}$

The most interesting historical model - which combines the upfront steer provided by prizes with something of the expansive culture of a system of rewards - is the operation of the Board of Longitude in the period after the controversy over Harrison's timepiece had been resolved. Over time the Board's mandate was expanded to allow it to make payments in relation to a broad range of nautical inventions. The Board's very existence sent a signal as to the types of invention that were important, and the Board could give further guidance as to research priorities, but the attempt to prescribe narrow

11 HC Deb 2 June 1802, page 596 per Mr Fuller MP. Jenner was committed to making his invention publicly available as soon as possible. Having tried, and failed, to find a willing patient for a public demonstration of vaccination in London, he self-published a guide to vaccination. See John Baron, Life of Edward Jenner (Henry Colburn 1827).

12 Dava Sobel in her enormously influential book on the Longitude Prize famously argued that the eventual recipient of the prize, John Harrison, was poorly treated by England's scientific establishment: Dava Sobel, Longitude: The True Story of a Lone Genius Who Solved the Greatest Scientific Problem of His Time (Walker and Co 1995). There is, however, a case to be made that the Board of Longitude did not act entirely unreasonably in refusing to grant Harrison the full prize. On this account Harrison was an awkward character whose endeavours were supported for many years by the Board despite his seeming reluctance to disclose the nature of his invention. See Jim Bennett, 'The travels and trials of Mr Harrison's timekeeper' in Marie N Bourguet, Christian Licoppe and H Otto Sibum (eds), Instruments, Travel and Science: Itineraries of Precision from the Seventeenth to the Twentieth Century (Routledge 2002); Katy Barrett, 'Explaining themselves: the Barrington Papers, the Board of Longitude, and the fate of John Harrison' (2011) 65 Notes and Records of the Royal Society of London 145. 
criteria for the award of a prize was largely abandoned. ${ }^{13}$ A pandemic prize fund modelled along these lines might have a number of advantages beyond correcting for market failure. The financial and reputational incentives provided by prizes are important, but history shows that prizes and rewards have other functions. In the eighteenth century, the reward system was self-consciously used by Parliament to send a signal that society valued scientific endeavour, that accumulation of wealth was not the only criterion by which to judge an individual's contribution to society, and that there was something noble about 'giving an invention to the world with liberality', 14 as unfashionable as that may now sound. Closely related to these other functions is the possibility that a pandemic prize fund might also echo the Parliamentary processes of the past and further the process of rehabilitating the role of the expert in public life, a process that, thankfully, already seems to be underway.

It is not possible to predict future pandemics. That the Spanish flu pandemic occurred almost exactly a century ago is purely a matter of chance; there is no epidemiological equivalent to Kondratieff long-wave cycles. The next pandemic might hit in two years or two hundred years, and it might take any number of forms. There does, nevertheless, appear to be a consensus around some of the areas where future research will be crucial if we are to be in a better position to fend off the next crisis. ${ }^{15}$ These include finding ways of predicting which animal pathogens are most likely to produce zoonotic diseases, tackling antimicrobial resistance (most immediately so that we can fight secondary bacterial infections during a viral pandemic, but in the longer term to guard against the renewed risk of bacterial pandemics), finding ways of accelerating the testing of vaccines without compromising patient safety, and developing new antivirals so that we have a greater range of therapies to test when confronted with a novel disease. These are some of the areas at which a new, flexible and open-ended pandemic prize fund might be targeted.

The establishment of a pandemic prize fund would, however, ideally form part of a comprehensive review of the benefits and costs of moving to a more proactive innovation policy. Such a review would not be a simple matter: the proactive/reactive distinction is a useful shorthand, but there are proactive elements of the current

13 This is an oversimplification of a complex topic, but the gradual expansion of the Board's remit is clear. See e.g. Peter Johnson, 'The Board of Longitude 1714-1828' (1989) 99 Journal of the British Astronomical Association 63, 68: 'With the award of the main prize to Harrison ... the Board had fulfilled its role under the 1714 Act. However, it was kept in being under a new Act of 1774 which moved the emphasis away from longitude to navigation in general. The scope of the Board became much wider'; Sophie Waring, 'The Board of Longitude and the funding of scientific work: negotiating authority and expertise in the early nineteenth century' (2014) 16 Journal for Maritime Research 55, 58: 'In the nineteenth century, the remit of the Board of Longitude was considerably widened as the Admiralty attempted to extract useful technologies from the scientific community after the decisive, if limited, success of the marine chronometer... [this] ... left the precise nature of scientific expertise that the board should support, and how it was meant to advise the Admiralty, increasingly vague ...' The flexible role of the Board in granting monetary awards meant that after 1800 the Board and Parliament presented alternative avenues by which inventors might seek recompense and recognition for their efforts. See Burrell and Kelly (n 3 above) 868. The Board had a number of ways of signalling its priorities, including by establishing sub-committees (although the history of these sub-committees is itself complex). We also acknowledge that the 1819 prize for discovering the north-west passage was run on the basis of precise navigational criteria, but this does not detract from the general thrust of the point being made here.

14 HC Deb 15 March 1802, page 203, per Admiral Berkeley: 'Jenner] had, with a generosity, liberality, and modesty, inseparable from true merit, communicated the result of his inquiries to the world. If he had pursued a contrary conduct, he would have realised a princely fortune.'

15 See also Bill Gates, 'Responding to Covid-19 - a once-in-a-century pandemic?' New England Journal of Medicine, 28 February 2020 <www.nejm.org/doi/full/10.1056/NEJMp2003762>. 
innovation policy landscape (as reflected in, for example, research council funding priorities). The patent system will remain important and thought needs to be given to how public funding of research, whether it comes in the form of grants or prizes, should bear on the rights of patent owners who have benefited from this funding. Some elements of the innovation policy landscape, such as $\mathrm{R} \& \mathrm{D}$ tax credits may, for better or worse, have an important role in international tax competition, irrespective of their impact on innovation outcomes. Thought also needs to be given to the time horizon in which innovation takes place. In the private sector there is the concern that the UK's model of corporate governance leads to a narrow and short-term focus on maximising share price at the expense of investment in technological advance. In the university sector difficult questions need to be asked about whether the REF-driven 'impact agenda' creates both a similar short-termism and a broader skewing effect (research bureaucrats across the land will soon be reappraising the work of those who not so long ago had been categorised as squandering opportunities to do 'impactful' research by wasting their time on novel corona viruses, disease transmission modelling, the history of pandemics and the optimal design of take-home examinations, to take just some of the more obvious examples).

Difficult questions and choices lie ahead, but if there is a positive to emerge from the current crisis it can only lie in forcing us to confront the need to do things differently. Critics have been arguing for years that the health innovation model is broken, but radical action has been ducked. There are, moreover, other areas where innovation is probably even more important. This is true for climate change mitigation technologies, bearing in mind that under some models of the impact of climate change worrying about the deaths of 50-100 million of us in a pandemic will seem quaint. Perhaps the best thing that we can do now is to create an expectation that innovation policy, like many other things, needs to change. There must be no return to the status quo ante. 